\title{
A secreted aspartic proteinase from Glomerella cingulata: purification of the enzyme and molecular cloning of the cDNA
}

\author{
Sarah J. Clark, ${ }^{1}$ Matthew D. Templeton ${ }^{2}$ and Patrick A. Sullivan ${ }^{3}$ \\ Author for correspondence: Patrick A. Sullivan. Tel: +64 6350 6272. Fax: +64 63505688. \\ e-mail: P.A.Sullivan@massey.ac.nz
}

1 Biochemistry Department, University of Otago, PO Box 56, Dunedin, New Zealand

2 Molecular Genetics Group, Horticulture and Food Research Institute of New Zealand Ltd, Mt Albert, Auckland, New Zealand

3 Biochemistry Department, Massey University, Private Bag 11222, Palmerston North, New Zealand

\begin{abstract}
A secreted aspartic proteinase from Glomerella cingulata (GcSAP) was purified to homogeneity by ion exchange chromatography. The enzyme has an $M_{r}$ of 36000 as estimated by SDS-PAGE, optimal activity from pH 3.5 to pH 4.0 and is inhibited by pepstatin. The $\mathbf{N}$-terminal sequence, 23 residues long, was used to design a gene-specific primer. This was used in $3^{\prime}$ RACE (rapid amplification of CDNA ends) PCR to amplify a $1.2 \mathrm{~kb}$ fragment of the gcsap CDNA. A second gene-specific primer was designed and used in $5^{\prime}$ RACE PCR to clone the 5 ' region. This yielded a 600 bp DNA fragment and completed the open reading frame. The gcsap open reading frame encodes a protein with a 78 residue prepro-sequence typical of other fungal secreted aspartic proteinases. Based on the deduced sequence, the mature enzyme contains 329 amino acids and shows approximately $\mathbf{4 0} \%$ identity to other fungal aspartic proteinases. Subsequent cloning and sequencing of gcsap fragments obtained from PCR with genomic DNA revealed a 73 bp intron beginning at nt 728 . Southern analyses at medium and high stringency indicated that G. cingulata possesses one gene for the secreted aspartic proteinase, and Northern blots indicated that gene expression was induced by exogenous protein and repressed by ammonium salts. GcSAP is a putative pathogenicity factor of G. cingulata, and it will now be possible to create SAP- mutants and assess the role GcSAP plays in pathogenicity.
\end{abstract}

Keywords: Glomerella cingulata, fungi, cDNA cloning, 3' and 5' RACE-PCR, secreted aspartic proteinase

\section{INTRODUCTION}

The plant-pathogenic fungus Glomerella cingulata (anamorph Colletotrichum gloeosporioides) causes anthracnose diseases of a variety of crops world-wide, but particularly in sub-tropical climates (Mordue, 1971; Irwin \& Cameron, 1978). Infection involves the attachment of the spore to the host surface, differentiation to form an appressorium and direct penetration of the cuticle and epidermal cell walls. It is widely accepted that penetration of the cuticle results from both the mechanical force generated by a high internal pressure in the appressorium, and the activity of cutinase secreted

\footnotetext{
Abbreviations: GCSAP, secreted aspartic proteinase from Glomerella cingulata; RACE, rapid amplification of CDNA ends.

The GenBank accession number for the nucleotide sequence reported in this paper is U43775.
}

by the fungus (Bailey et al., 1993). The subsequent development of the infection depends on the secretion of an array of enzymes, such as endopolygalacturonases, cellulases, pectin lyase, xylanase and $\beta$-galactosidase (for reviews see Collmer \& Keen, 1986; Bailey et al., 1993; Cooper, 1977) which in concert degrade structural components of plant tissue.

Extracellular proteinases, especially those of animal pathogens, have been widely implicated as pathogenicity factors for several decades (for a review see Ogrydziak, 1993), but remarkably few of these studies have encompassed the proteinases produced by phytopathogenic fungi. Studies of an aspartic proteinase of Botrytis cinerea (Movahedi \& Heale, 1990) showed that secretion of this enzyme is an early event in infection by $B$. cinerea, occurring before pectic enzyme production. Proteinase activity caused plant cell death and significantly higher levels of activity were secreted by virulent 
compared with less virulent strains of the fungus. It is also noteworthy that proteinase inhibitors are widespread in the plant kingdom (for reviews see Ryan, 1973; Aviles, 1993) and it has been shown that inhibitor activity in melon seedlings infected with Colletotrichum lagenarium increased sharply $3 \mathrm{~d}$ after spore inoculation (Roby et al., 1987). Similarly, accumulation of a trypsin inhibitor in tomato plants has been correlated with resistance to Phytophthora infestans (Peng \& Black, 1976). Collectively, these studies suggest, but do not unequivocally establish, that proteinases have significant roles in pathogenicity.

Production of a proteolytic activity by G. cingulata was first detected when sections of apple fruit rotted by $G$. cingulata were assayed for enzyme activity (Kuc \& Williams, 1962). More recently, G. cingulata has become a particularly suitable organism for the assessment of putative pathogenicity factors with the development of protocols for targeted gene disruptions (Rikkerink et al., 1994; Bowen et al., 1995) and the identification of genes selectively expressed during appressorium formation (Hwang \& Kolatukudy, 1995). It should now be possible to assess the roles of the secreted proteinase, and as a first step towards this objective we describe here the purification of a G. cingulata secreted aspartic proteinase (GcASP), some properties of the enzyme, and molecular cloning of the cDNA and the gene encoding the enzyme.

\section{METHODS}

Organisms and plasmids. G. cingulata was obtained from the International Collection of Micro-organisms from Plants (ICMP), Maanaki Whenua Landcare NZ. Escherichia coli strain DH5 $\alpha$ was the host for recombinant plasmids. The plasmid pBluescript KS II $(+)$ (Stratagene) was used for cloning experiments.

Media and reagents. G. cingulata cultures were maintained on potato dextrose agar. E. coli cultures were grown in Luria broth, supplemented with ampicillin as required (Sambrook $e t$ al., 1989). BSA (fraction V) was obtained from Boehringer Mannheim, and bovine haemoglobin (type II) was supplied by Sigma. Taq DNA polymerase and SUPERSCRIPT RNase $\mathrm{H}^{-}$ reverse transcriptase were from Gibco BRL. Oligonucleotides were produced by an Applied Biosystems 380B synthesizer using $\beta$-cyanoethyl chemistry.

Enzyme purification. Twenty $200 \mathrm{ml}$ cultures of G. cingulata were grown in a nitrogen-free salts medium (Wickerham, 1946) containing $0.2 \%(\mathrm{w} / \mathrm{v}) \mathrm{BSA}$ and $2 \%(\mathrm{w} / \mathrm{v})$ glucose (static for $3 \mathrm{~d}$ in 11 Roux flasks at $26^{\circ} \mathrm{C}$ ). After harvesting the mycelium by centrifugation, the supernatant was adjusted to $\mathrm{pH} 7.0$ with $6 \mathrm{M} \mathrm{NaOH}$ and concentrated to approximately $500 \mathrm{ml}$ by ultrafiltration (molecular mass cut-off $10000 \mathrm{Da}$ ). After dialysis for $17 \mathrm{~h}$ against $10 \mathrm{mM}$ sodium citrate buffer, $\mathrm{pH} 6 \cdot 8$, the concentrate was applied to a DEAE-Sepharose column $(2.5 \times 17 \mathrm{~cm})$ equilibrated with buffer, and the column washed with similar buffer at a flow rate of $1 \mathrm{ml} \mathrm{min}^{-1}$ until the $A_{280}$ returned to zero. Bound protein was eluted with a linear gradient of 10 to $250 \mathrm{mM}$ sodium citrate, $\mathrm{pH} 6.3$ $(400 \mathrm{ml})$ and was collected in $10 \mathrm{ml}$ fractions. Fractions $15-30$ contained proteinase activity and were pooled and con- centrated to approximately $15 \mathrm{ml}$ by ultrafiltration and dialysed against $20 \mathrm{mM}$ Bis-tris buffer, $\mathrm{pH} 6 \cdot 0$ (fraction 1). Aliquots $(0.8 \mathrm{ml})$ of this concentrate were applied to a Mono Q HR 5/5 column (Pharmacia) equilibrated in the same buffer. The column was eluted with a gradient of 0 to $200 \mathrm{mM}$ $\mathrm{NaCl}$ in $20 \mathrm{mM}$ Bis-tris, $\mathrm{pH} 6.3$, over 30 min at a flow rate of $0.75 \mathrm{ml} \mathrm{min}^{-1}$. Fractions containing the enzyme were pooled and stored at $-20{ }^{\circ} \mathrm{C}$ (fraction 2).

Proteinase enzyme assays. Proteinase activity was estimated by measuring the hydrolysis of (a) BSA or (b) haemoglobin. Enzyme activity was also detected in the growth medium with Azocoll (Calbiochem).

BSA assay. This was based on the assay of MacDonald \& Odds (1980). Each assay mixture contained $0.6 \mathrm{ml} 1 \%$ BSA in $50 \mathrm{mM}$ sodium citrate buffer, $\mathrm{pH} 3 \cdot 2$, and $0.2 \mathrm{ml}$ enzyme solution. After $2 \mathrm{~h}$ at $37^{\circ} \mathrm{C}, 0.4 \mathrm{ml} 10 \%(\mathrm{w} / \mathrm{v})$ trichloroacetic acid was added, the tubes were stored on ice for $10 \mathrm{~min}$ and then centrifuged ( 13000 r.p.m. for $10 \mathrm{~min}$ ). The absorbance of the supernatant was read at $280 \mathrm{~nm}$ and corrected for background using a zero-time control in which trichloroacetic acid was added prior to the enzyme. One unit of enzyme was defined as that amount which catalysed a change in $A_{280}$ of $1.0 \mathrm{~min}^{-1}$.

Haemoglobin assay. Each assay mixture contained $0.2 \mathrm{ml}$ enzyme solution and $1 \mathrm{ml}$ acid-denatured haemoglobin [ $2 \%$ $(\mathrm{w} / \mathrm{v})$ in $0.2 \mathrm{M}$ glycine/ $\mathrm{HCl}, \mathrm{pH} \mathrm{3.5]}$. After incubation at $30{ }^{\circ} \mathrm{C}$ for $30 \mathrm{~min}$, a $300 \mu \mathrm{l}$ aliquot was mixed with $200 \mu \mathrm{l} 10 \%$ trichloroacetic acid and incubated on ice for $10 \mathrm{~min}$ before being centrifuged at 3600 r.p.m. for $10 \mathrm{~min}$. Zero-time controls were obtained by taking a $300 \mu \mathrm{l}$ aliquot of the assay immediately after the enzyme was added. Samples $(75 \mu \mathrm{l})$ of the supernatant were neutralized with $75 \mu \mathrm{l} 0.5 \mathrm{M} \mathrm{NaOH}$ and assayed for soluble peptides by the Lowry method using tyrosine as a standard. One unit of enzyme activity was defined as that amount which released $1 \mu \mathrm{mol}$ tyrosine equivalents $\mathrm{min}^{-1}$.

Protein estimations. These were performed using the bicinchoninic acid (BCA) assay (Smith et al., 1985).

SDSPAGE and electrotransfer. SDS-PAGE was carried out with $10 \%(\mathrm{w} / \mathrm{v})$ acrylamide gels (Laemmli \& Favre, 1973) and the following proteins were used as molecular mass standards: $\beta$-galactosidase (116 kDa), phosphorylase b $(97.4 \mathrm{kDa})$, BSA $(66 \mathrm{kDa})$, ovalbumin $(45 \mathrm{kDa})$, carbonic anhydrase $(29 \mathrm{kDa})$ and cytochrome $c(12.5 \mathrm{kDa})$. Electrotransfer to a PVDF membrane (Problott) was done in buffer consisting of $96 \mathrm{mM}$ glycine, $12.5 \mathrm{mM}$ Tris $/ \mathrm{HCl}, \mathrm{pH} 8.3$ and $20 \%$ (v/v) methanol. After $2 \mathrm{~h}$ at $75 \mathrm{~V}$ and $250 \mathrm{~mA}$, the transfer was visualized with $0.1 \%$ Ponceau $S$ in $1 \%$ acetic acid. The membrane was destained in $1 \%$ acetic acid, washed with distilled water and blotted dry between filter paper.

$\mathbf{N}$-terminal sequencing. The proteinase was sequenced on an Applied Biosystems (ABI) 470A/170A on-line gas-phase sequencer using standard ABI protocols. Stained protein bands on the Problott membrane were excised and directly applied to the sequencer. A total of approximately 200 pmol protein was applied for analysis.

DNA and RNA manipulations. Restriction endonucleases and DNA-modifying enzymes were incubated under the conditions recommended by the suppliers. Standard conditions for molecular cloning, hybridization, transformation and electrophoresis were used (Sambrook et al., 1989). Molecular mass markers were HindIII fragments of bacteriophage I (Gibco 
BRL). Purification of DNA fragments from agarose gels was done as described by Vogelstein \& Gillespie (1979). DNA sequencing was performed on an ABI 373A automated sequencer using standard ABI protocols. G. cingulata DNA was isolated as described by Raeder \& Broda (1985). G. cingulata RNA for RACE was extracted from either $48 \mathrm{~h}$ stationary cultures or $36 \mathrm{~h}$ shake cultures by the methods of Carlson \& Botstein (1982) and Teeri et al. (1987), respectively. These cultures were grown in the BSA medium described above. The method of Teeri et al. (1987) was also used to extract RNA for Northern analysis. Poly $\left(\mathrm{A}^{+}\right)$RNA was purified from $1 \mathrm{mg}$ total RNA in a batchwise manner using $30 \mathrm{mg}$ microcrystalline oligo (dT)-cellulose (New England Biolabs). Binding and elution buffers used were those recommended by the manufacturer. For Southern blotting, the membranes were hybridized at $56^{\circ} \mathrm{C}$ and then washed as follows : twice with $2 \times \mathrm{SSC}(1 \times \mathrm{SSC}$ is $0.15 \mathrm{M} \mathrm{NaCl}, 0.015 \mathrm{M}$ sodium citrate), $0.5 \%$ SDS at room temperature for $10 \mathrm{~min}$, and then $2 \times \mathrm{SSC}, 0.5 \%$ SDS at $63^{\circ} \mathrm{C}$ for $1 \mathrm{~h}$ (medium stringency). This was followed by a higher stringency wash of $0.1 \times \mathrm{SSC}, 0.5 \%$ SDS at $68^{\circ} \mathrm{C}$ for $1 \mathrm{~h}$. Northern membranes were hybridized at $65^{\circ} \mathrm{C}$ and then washed twice with $2 \times \mathrm{SSC}$, $0.5 \% \mathrm{SDS}$ at room temperature for $15 \mathrm{~min}$, and then twice at $65^{\circ} \mathrm{C}$ for $10 \mathrm{~min}$.

\section{Rapid amplification of CDNA ends (RACE)}

$3^{\prime}$ RACE. The basic protocol for $3^{\prime}$ RACE was that described by Ausubel et al. (1992). Three primers were required. A gene-specific oligonucleotide (SAP-primer1) [5'GGGGTACCAGGA(C/T)TA(C/T)GA(C/T)GT(A/G)AG$(\mathrm{G} / \mathrm{A} / \mathrm{C} / \mathrm{T}) \mathrm{TA}]$ was based on the sequence of amino acid residues QDYDVEY in the determined $\mathrm{N}$-terminal sequence of mature GcSAP. SAP-primer1 also contained a $K p n I$ site. A poly $T$ primer $\left[5^{\prime}-\right.$ GGGGTACCGTCGACATCGA $\left.\left(T_{12}\right)\right]$ that contained an adaptor sequence was used in first strand cDNA synthesis. The adaptor sequence contains restriction sites for $K p n I$, SalI and ClaI, and an adaptor primer containing this sequence (5'-GGGGTACCGTCGACATCGA) was made for use in PCR with SAP-primer1. Total RNA was reversetranscribed under conditions recommended by Gibco BRL. For $20 \mu \mathrm{l}$ PCR reactions, $2 \mu$ l undiluted cDNA was used. Optimized PCR conditions included 5 cycles with an annealing temperature of $56^{\circ} \mathrm{C}$ and a further 35 cycles with annealing at $55^{\circ} \mathrm{C}$. The $\mathrm{MgCl}_{2}$ concentration was $2.5 \mathrm{mM}$.

5 ' RACE. This was performed using the $5^{\prime}$-AmpliFINDER RACE kit from Clontech. Two gene-specific primers were synthesized. Oligonucleotide SAP-primer2 (5'GCTCTAGAAAAAAGTCTTCTG) contained sequence complementary to the region from nt 652 to 666 as well as a restriction site for $X b a I$ and was used to make first strand cDNA. Oligonucleotide SAP-primer4 (5'GGGGTACCGTAGGAGATGGACCA) contained sequence complementary to the region from nt 454 to 470 and a restriction site for $K p n$ I. After first strand cDNA had been made, AmpliFINDER anchors were ligated to the $3^{\prime}$ ends of the cDNAs under conditions recommended by Clontech. The anchored cDNA was used in PCR with SAP-primer4 and an anchor primer provided in the 5' RACE kit. The anchor primer contained an EcoRI site. Optimized PCR conditions included an annealing temperature of $60^{\circ} \mathrm{C}$ and a $\mathrm{MgCl}_{2}$ concentration of $2.5 \mathrm{mM}$ in a reaction volume of $50 \mu \mathrm{l}$.

PCR of a genomic sap fragment. $G$. cingulata genomic DNA was used as the template in a PCR reaction with primers SAP-primer1 and SAP-primer3 (5'GGGGTACCATCGAAGACAACGAA). SAP-primer3 contained sequence complementary to the region from nt 1238 to
1255. Annealing was done at $57^{\circ} \mathrm{C}$ for 5 cycles, then at $56^{\circ} \mathrm{C}$ for 30 cycles. The $\mathrm{MgCl}_{2}$ concentration was $2.5 \mathrm{mM}$.

Computer programs. Editing, analysis and alignment of sequences was carried out using the ABI SeqEd Macintosh program, and PILEUP, LINEUP and SEQED programs from the Genetics Computer Group (Wisconsin Sequence Analysis Package, version 8). Autoradiograms were scanned with a BioRad GS-670 Imaging densitometer and the digital images were processed with Adobe Photoshop 3.0 and Canvas 3.5.1 from Denaba systems.

\section{RESULTS AND DISCUSSION}

\section{Induction and purification of GcSAP}

Providing protein as the sole nitrogen source in fungal cultures has been widely documented as a system for induction of proteinase production (Ross et al., 1990, and references cited therein) and this strategy was used for G. cingulata proteinase induction. G. cingulata grew well when cultured in salts medium containing either $\left(\mathrm{NH}_{4}\right)_{2} \mathrm{SO}_{4}$ or BSA as the sole nitrogen source. Proteinase activity in the culture medium was monitored for $5 \mathrm{~d}$ and detected in the BSA cultures in assays with either BSA or Azocoll as the substrate. Maximum proteinase activity was observed on day 3 in the BSA medium and there was no proteinase activity in the medium in which $\left(\mathrm{NH}_{4}\right)_{2} \mathrm{SO}_{4}$ was the nitrogen source.

For proteinase enzyme purification (see Methods for details), G. cingulata was cultured in BSA medium for $3 \mathrm{~d}$. Following concentration by ultrafiltration, the growth medium was dialysed against $10 \mathrm{mM}$ sodium citrate buffer, $\mathrm{pH} 6 \cdot 8$, and the crude enzyme was applied

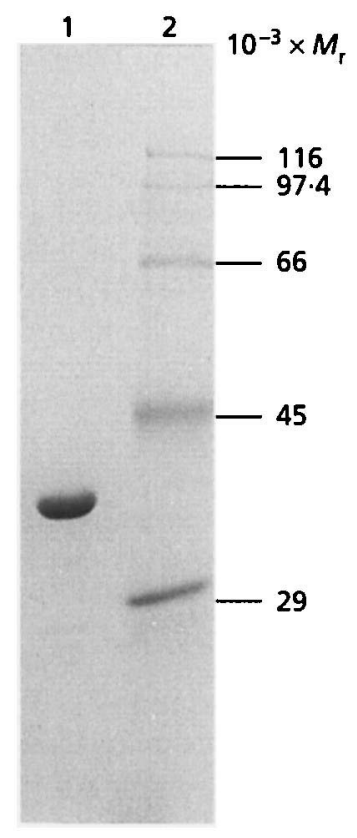

Fig. 1. SDS-PAGE of GCSAP. Lane 1, purified GCSAP (10 $\mu \mathrm{g}$ of fraction 2, as described in Table 1); lane 2, molecular mass standards as indicated on the right. 
Table 1. Purification of GCSAP

\begin{tabular}{|lccccc|}
\hline Fraction* & $\begin{array}{c}\text { Volume } \\
(\mathrm{ml})\end{array}$ & $\begin{array}{c}\text { Activity } \\
(\mathbf{U}) \dagger\end{array}$ & $\begin{array}{c}\text { Protein } \\
(\mathbf{m g})\end{array}$ & $\begin{array}{c}\text { Specific activity } \\
\left(\mathbf{U} \mathbf{~ m g}^{-1}\right)\end{array}$ & $\begin{array}{c}\text { Yield } \\
(\%)\end{array}$ \\
\hline $\mathrm{F}_{0-\mathrm{C}}$ & 544 & 10.5 & 6800 & 0.0015 & 100 \\
$\mathrm{~F}_{1}$ & 14.5 & 6.3 & $8 \cdot 7$ & 0.7 & 60 \\
$\mathrm{~F}_{2}$ & 10.5 & 1.5 & $2 \cdot 0$ & 0.8 & 14 \\
\hline
\end{tabular}

${ }^{*} \mathrm{~F}_{0-\mathrm{C}}$, concentrated growth medium; $\mathrm{F}_{1}$, concentrated dialysed fraction from DEAE-Sepharose chromatography; $F_{2}$, pooled active fractions (peak 3) from Mono $Q$ chromatography.

† Activity was measured in the BSA assay (see Methods).

to a DEAE-Sepharose column. Most of the protein, as judged by the $A_{280}$ profile, was eluted during loading, washing with buffer, and in the $10-100 \mathrm{mM}$ sodium citrate gradient. The proteinase was recovered in fractions $15-30$ from $100-200 \mathrm{mM}$ sodium citrate, $\mathrm{pH}$ 6.3 . These fractions were pooled, concentrated and dialysed against $20 \mathrm{mM}$ Bis-tris buffer, $\mathrm{pH} 6.0$ (fraction 1). Separation of proteinase from other proteins was achieved by chromatography on a Mono $Q$ column with a gradient of $0-200 \mathrm{mM} \mathrm{NaCl}$ in Bis-tris buffer, $\mathrm{pH} 6 \cdot 3$. The third and final peak contained the activity and a single protein of $36 \mathrm{kDa}$ as judged by SDS-PAGE electrophoresis (Fig. 1). No other proteinase activity was detected during the fractionation. Table 1 summarizes the purification of GcSAP.

\section{Properties of GCSAP}

GcSAP exhibited properties typical of a fungal secreted aspartic proteinase. In assays with haemoglobin as substrate maximum activity was at $\mathrm{pH} 3 \cdot 5-4 \cdot 0$. However, in contrast with other secreted aspartic proteinases, significant activity was observed over a wide range $(\mathrm{pH}$ $2 \cdot 0-7 \cdot 0$ ) and at $\mathrm{pH} 7 \cdot 0$ was $40 \%$ of the maximum value (data not shown). The activity was completely inhibited by pepstatin, a specific aspartic proteinase inhibitor. The purified GcSAP also degraded BSA, keratin and casein, but haemoglobin was the best substrate. The specific activity of purified GcSAP in the BSA assay was $0.8 \mathrm{U} \mathrm{mg}^{-1}$ which is low compared to SAP2 from Candida albicans, which has an activity of $6.8 \mathrm{U} \mathrm{mg}^{-1}$ (Wright et al., 1992). However, the specific activity of GcSAP in the haemoglobin assay $\left(4 \cdot 1 \mathrm{U} \mathrm{mg}^{-1}\right)$ is comparable to the reported value for the secreted aspartic proteinase from $B$. cinerea $\left(3 \cdot 1 \mathrm{U} \mathrm{mg}^{-1}\right)$ assayed under the same conditions (Movahedi \& Heale, 1990).

\section{$\mathbf{N}$-terminal sequence of GcSAP}

GcSAP was electroblotted onto a PVDF membrane and subjected to automated Edman degradation. This yielded a sequence of 23 residues (ATGSVAATPQDYDVEYLSPV?IG) and was subsequently matched with amino acids $79-102$ of the deduced sequence (Fig. 2). This experimentally determined N-terminus has $74 \%$ similarity and $57 \%$ identity when aligned with the $\mathrm{N}$-terminal sequences of
Rhizopus chinensis rhizopuspepsin II and Rhizopus niveus aspartic proteinase 1, as shown in Fig. 3.

\section{Cloning and sequencing of the gcsap CDNA}

$3^{\prime}$ RACE. Total RNA was extracted from G. cingulata grown in BSA medium and used to make cDNA templates for PCR. Based on the size of the GcSAP protein, the lengths of typical $3^{\prime}$ untranslated sequences and poly $\left(\mathrm{A}^{+}\right)$tails associated with eukaryotic mRNA transcripts, it was anticipated that the PCR product would be approximately $1.2 \mathrm{~kb}$. PCR with the adaptor primer and gene-specific primer SAP-primer1 yielded two products close to the expected size $(1.2 \mathrm{~kb}$ and $990 \mathrm{bp}$ ). Control PCR reactions were performed with only one primer (the adaptor primer) and cDNA was derived from either $\left(\mathrm{NH}_{4}\right)_{2} \mathrm{SO}_{4}$ or BSA cultures. These eliminated the $990 \mathrm{bp}$ PCR product as a gcsap fragment, and the $1.2 \mathrm{~kb}$ product was reamplified from a band stab. The amplified fragment was digested with $K p n \mathrm{I}$, gel-purified and ligated into the KpnI site of pBluescript $\mathrm{KS} \mathrm{II}(+)$, yielding $\mathrm{pSJ} 1$. Sequencing of $\mathrm{pSJ1}$ confirmed that the PCR product coded for the gcsap cDNA because the deduced amino acid sequence matched exactly with the N-terminus of GcSAP determined by the Edman degradation. The gcsap cDNA fragment consisted of $960 \mathrm{bp}$ of coding sequence, which represented $97 \%$ of the mature protein, and contained $200 \mathrm{bp}$ of downstream sequence (Fig. 2).

$5^{\prime}$ RACE. $\operatorname{Poly}\left(\mathrm{A}^{+}\right) \mathrm{RNA}$ was purified from RNA enriched with the transcript of GcSAP and used to make the cDNA template for PCR. Following the ligation of an anchor oligonucleotide to the $3^{\prime}$ ends of the cDNA preparation, PCR was performed using the anchor primer and the gene-specific primer SAP-primer4. One product of $600 \mathrm{bp}$ was observed on agarose gels and this was subsequently cloned between the $K p n \mathrm{I}$ and EcoRI sites of pBluescript $\mathrm{KS} \mathrm{II}(+)$. Two clones were sequenced and this confirmed that the PCR product was the $5^{\prime}$ region of the gcsap cDNA. The $5^{\prime} \mathrm{cDNA}$ fragment contains $104 \mathrm{bp}$ of upstream noncoding sequence and $234 \mathrm{bp}$ of sequence downstream of the initiation ATG that encodes a typical prepro-sequence of 78 amino acids, and this is followed by sequence coding for the mature protein. This sequence matched exactly that previously determined by $3^{\prime}$ RACE. 


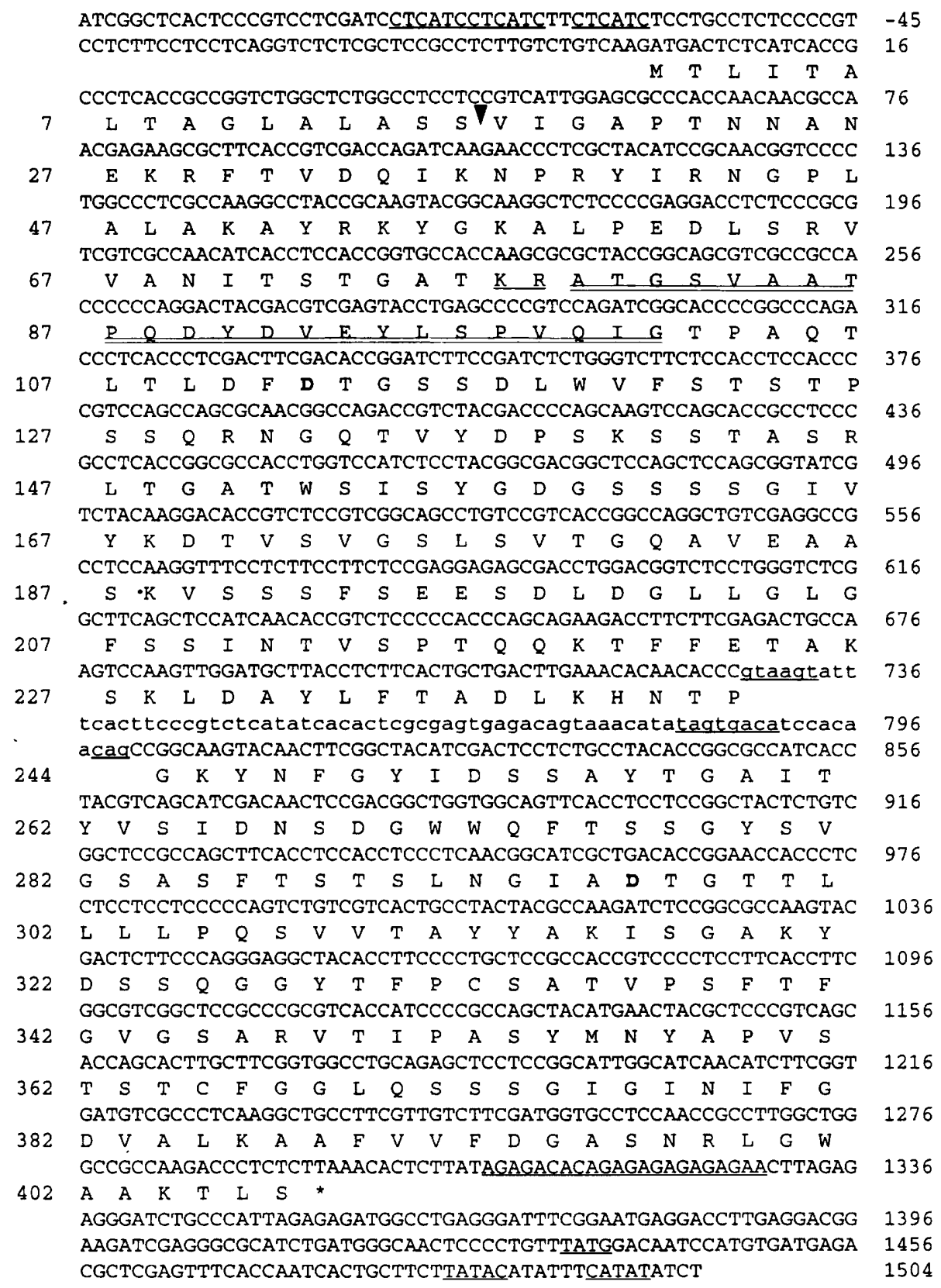

Fig. 2. Nucleotide sequence of gcsap and derived amino acid sequence. These data were obtained from CDNA and genomic clones. The predicted signal peptidase and KEX2 processing sites in the prepro-sequence are indicated by ( $\nabla)$ and underlined text $(K R)$ respectively. The $\mathrm{N}$-terminal sequence data determined by Edman degradation are doubleunderlined. The conserved and repeated nucleotide sequences in untranslated regions, as discussed in the text, are underlined. The intron (nt 728-800) is in lower case letters.

\section{Intervening sequence}

Genomic sequence of the gcsap gene was obtained by performing PCR with SAP-primer1 and SAP-primer3 using genomic DNA as the template. A single product of $950 \mathrm{bp}$ was produced and cloned into the $K p n I$ site of pBluescript KS II $(+)$. Sequencing of the resulting clone revealed a $73 \mathrm{bp}$ intron beginning at nt 728 (Fig. 2). The intron/exon splice junctions (GTAAG and CAG) and putative lariat structure (TAGTGACA) fit the consensus sequences found in other filamentous fungi (Gurr et al., 1987).

\section{The untranslated sequences}

The $5^{\prime}$ untranslated region contains a triple repeat of the motif CTCATC between nt -80 and -61 (Fig. 2). Similar repeats have been detected in the same region of many Aspergillus nidulans genes (Ward \& Turner, 1986) 
1

GCSAP MTLITALT AGLALASSVI GAPTINAN .

RCaspII MKFTLISSCI AIAALAVAVD AAP................

Rnasp1 MKFTLISSCV ALAAMTLAVE AAP....... . NGKKINIPL AKNNSYKPSA KNALNKALAK YNR......

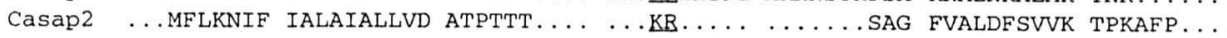

Mmasp MLFSQITSAI LLTAASLSLT TARPVSKQSE SKDKLLALPL TSVSRKFSQT KFGQQQLAEK LAGLKPF.. 71

GCSAP RVVANITSTG ATKRATGSVA. ATPODYDVEY LSPVQTGTPA OTLTLDFDTG SSDLWV. FS TSTPS 140

RCaSPII HKINTSTGGI VPDAGVGTVP MTDYGNDVEY YGQVTIGTPG KKFNLDFDTG SSDLWI..AS TLCTN....

Rnasp1 RKV..GSGGI TTEAS.GSVP MVDYENDVEY YGEVTVGTPG IKLKLDFDTG SSDMWF..AS TLCSS....

Casap2 ..VTNGQEGK TSKR..QAVP VTLHNEQVTY AADITVGSNN QKLNVIVDTG SSDLWVPDVN VDCQVTYSDQ

Mmasp ........SE AADGSVDTPG YYDFDLE.EY AIFVSIGTPG QDFLLLFDTG SSDTWVPH.. KGCTKSEG.

141

210

GCSAP ...SQRNGQ. TVYDPSKSST ASRLTGATWS ISYGDGSSSS GIVYKDTVSV GSLSVTGQAV EAASKVSSSF

RCaspII ....CGSRQ. TKYDPKQSST YQ.ADGRTWS ISYGDGSSAS GILAKDNVNL GGLLIKGQTI ELAKREAASF

Rnasp1 ....CSNSH. TKYDPKKSST YA.ADGRTWS ISYGDGSSAS GILATDNVNL GGLLIKKOTI ELAKRESSAF

Casap2 TADFCK.QKG T.YDPSGSSA SQ.DLNTPFK IGYGDGSSSQ GTLYKDTVGF GGVSIKNQVL ADVDSTSID.

Mmasp ...... .GS RFFDPSASST F. KATNYNLN ITYGTG.GAN GLYFEDSIAI GDITVTKQIL AYVDNVRGPT

211

280

GCSAP SEESD.... LDGLLGLGFS SINT....V SPTQ...QKT FFETAKSKLD AYLFTADLKH NTPGKYNFGY

RCaspII ANGPN...... .DGLLGLGFD TITT....V RGVKTPMDNL ISQGLISRPI FGVYLGKASN GGGGEYIFGG

Rnasp1 ATDVI...... DGLLGLGFN TITT.....V RGVKTPVDNL ISQGLISRPI FGVYLGKQSN GGGGEYIFGG

Casap2 ......... QGILGVGYK TNEA....G GSYDNVPVTL KKQGVIAKNA YSLYLNSPD. A.ATGQIIFGG

Mmasp AEQSPNADIF LDGLFGAAYP DNTAMEAEYG STYNTVHVNL YKQGLISSPL FSVYMN..TN SGTGEVVFGG

281

281

RCaSPII YDSTKFKGSL TTVPIDNSRG ...WWGITVD RATVG.TSTV . . ASSFDGIL DTGTTLLILP NN.VAASVAR

Rnasp1 YDSSKFKGSL TTVPIDNSEG ...FWGVTVK STKIG.GTTV ..SASFDAIL DTGTTLLLLP DD.VAAKVAR

Casap2 VDNAKYSGSL IALPVTSD.R . . ELRISLG SVEVS.GKTI N.TDNVDVLL DSGTTITYLQ QD.LADQIIK

Mmasp VNNTLLGGDI AYTDVMSRYG GYYFWDAPVT GITVDGSAAV RFSRPQAFTI DTGTNFFIMP SS.AASKIVK

$351 \quad 420$

GCSAP ISGAKYDSSQ GG... YTFP CSAT.VPSFT FGV...... GSARVTIPAS YMN. YAPVS TS...TCFGG

RCaspII AYGAS.DNGD GT....YTIS CDTSRFKPLV FSI...... NGASFQVSPD SLV..FEEYQ . G...QCIAG

Rnasp1 SYGAS.DNGD GT....YSIT CDTSKLQPLV FTL...... GSSTFEVPSD SLI..FEKDG .N...KCIAG

Casap2 AFNGK.LTQD SNGNSFYEVD CNLSGD.VVF NFS...... KNAKISVPAS EFAASLQGDD GQPYDKCQLL

Mmasp AALPDATETQ QG....WVVP CASYQNSKST ISIVMQKSGS SSDTIEISVP VSKMLLPVDQ SNE. TCMFI

421

GCSAP LQSSSGIGIN IFGDVALKAA FVVFDGASNR LGWAAKTLS* .......

RCaSPII F.GYGNFDFA IIGDTFLKNN YVVFNQGVPE VQIAPVAQ* $\ldots \ldots \ldots$

Rnasp1 F.AAGG.DLA ILGDVFLKNN YVVFNQEVPE VQIAPVAN ${ }^{\star} \ldots \ldots \ldots \ldots$

Casap2 F.DVNDA. .N ILGDNFLRSA YIVYDLDDNE ISLAQVKYTS ASSISALT*

MmasP I.LPDGGNQY IVGNLFLRFF VNVYDFGNNR IGFAPLASAY ENE* ....

Fig. 3. Alignment of fungal aspartic proteinases. GcSAP, secreted aspartic proteinase of G. cingulata (GenBank accession number U43775); Rcaspli, R. chinensis rhizopuspepsin If (L33857); Rnasp1, R. niveus aspartic proteinase 1 (Horiuchi et al., 1988, M19100); Casap2, C. albicans SAP2 (Wright et al., 1992, M83663); Mmasp, M. miehei aspartic proteinase (Gray et al., 1986, M15267). Paired basic amino acids in the prepro-sequence are underlined and the $\mathrm{N}$-terminal residues of the mature enzymes are in bold type and underlined. The catalytic aspartic residues are in bold type, and conserved cysteine residues are indicated by shading.

and also $5^{\prime}$ of the initiation ATG of the $g p d A$ gene of $G$. cingulata (Templeton et al., 1992). The sequence directly upstream of the start codon (CAAGATGAC) closely resembles the consensus sequence $\left(\mathrm{CA}^{\mathrm{C}} / \mathrm{A} / \mathrm{C}\right.$ CATGGC) for filamentous fungi, although a $G$ in the -1 position is rare (Gurr et al., 1987).

The $3^{\prime}$ region of the gcsap cDNA was cloned using a poly $(T)$ primer which presumably annealed to the poly $\left(\mathrm{A}^{+}\right)$region of the mRNA. However, there is no consensus eukaryotic polyadenylation signal (AAUAAA) in the $3^{\prime}$ untranslated region. But this region (nt 1309-1504) contains a number of intriguing features : the sequence from nt 1309 to 1328 contains eight GA repeats; there are two copies of a GAGGAC motif between nt 1380 and 1394; and a palindrome of the motif TATAC is located 5-20 nt before the end of the sequence. The significance of these features is not known.

\section{Analysis of genomic DNA}

Southern analysis was used to determine the copy number and to detect any closely homologous genes in the genome. Genomic DNA from $G$. cingulata was digested with EcoRI, BamHI and KpnI, which do not cut within the cloned sequence, and with SalI, PstI, Sacl and $B g l I I$, which each cut once within the sequence. Hybridization with a 950 bp probe and washing at both medium and high stringency revealed one band in each digest, except for the BglII digest which had a major 
(a)

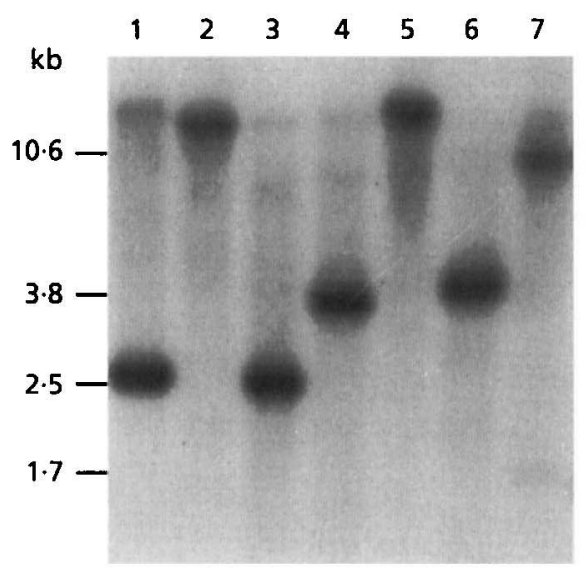

(b)

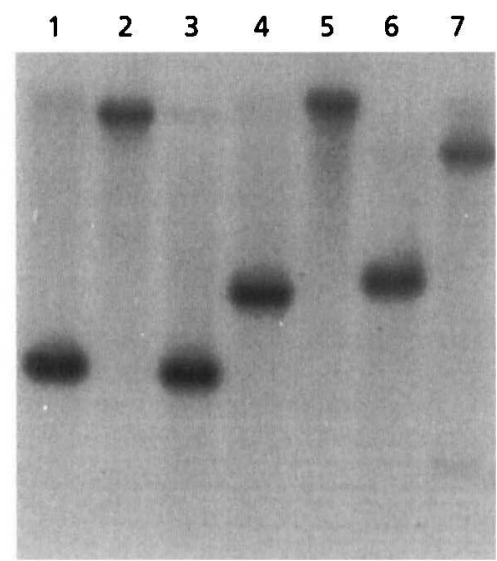

Fig. 4. Southern analysis of gcsap. A Southern blot of restriction-enzyme-digested genomic DNA was probed with a 950 bp gene fragment. The region of the gene covered by the probe is shown in Fig. 5. Lanes: 1, EcoRI; 2, BamHI; 3, Pstl; 4, SaCl; 5, Kpnl; 6, Sall; 7, Bglll. (a) Membrane washed at medium stringency; (b) membrane washed at high stringency (see Methods).

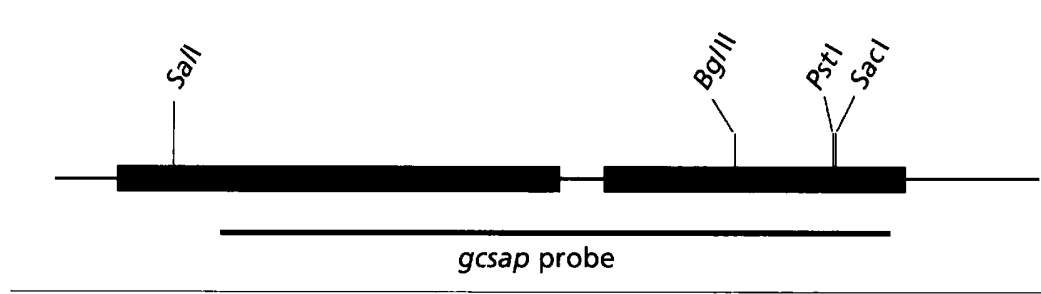

Fig. 5. Restriction map of the gcsap gene sequence. The PCR product amplified from genomic DNA using SAP-primer1 and SAPprimer3 (see Methods) was cloned and used as a probe, and this is represented by the solid line below the map. The coding regions are represented by the black boxes. The intron and other untranslated regions are shown as a narrow line.

band at $10.6 \mathrm{~kb}$ and a faint band at $1.7 \mathrm{~kb}$ (Fig. $4 \mathrm{a}, \mathrm{b}$ ). These results are consistent with the restriction map of the gcsap gene and the region covered by the probe (Fig. 5). The Sall site is upstream from the region which hybridized to the probe and the second PstI and SacI fragments only overlap the probe by $70 \mathrm{bp}$ and were not detected. These results indicate that the genome does not contain other genes that are closely related to gcsap.

\section{Expression of gcsap}

The secretion of GcSAP is induced by exogenous protein and repressed by ammonium salts. A Northern analysis indicated that this regulation is at the level of transcription. As shown in Fig. 6, a transcript of $1.7 \mathrm{~kb}$ was detected when BSA was the sole nitrogen source but was absent when $\mathrm{NH}_{4} \mathrm{Cl}$ was the sole nitrogen source. These results are consistent with the pattern of proteinase secretion under these growth conditions. There was also no gcsap transcript detected when the growth media contained both BSA and $\mathrm{NH}_{4} \mathrm{Cl}$, indicating that ammonium salts repressed expression of the gene.

\section{The amino acid sequence}

The deduced amino acid sequence of GcSAP is $38 \%$ and $51 \%$ identical with rhizopuspepsin (Delany et al., 1987) and penicillopepsin (James \& Sielecki, 1983) respect-

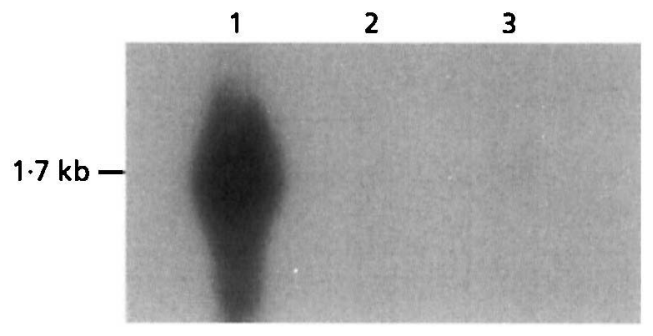

Fig. 6. Northern analysis of gcsap. G. cingulata was grown in media where the nitrogen source was either BSA (lane 1), $\mathrm{NH}_{4} \mathrm{Cl}$ (lane 2) or BSA $+\mathrm{NH}_{4} \mathrm{Cl}$ (lane 3). RNA was extracted after $48 \mathrm{~h}$ growth and analysed with the probe illustrated in Fig. 5. All lanes contained approximately the same amount of total RNA.

ively. The alignment in Fig. 3 indicates in particular that the regions surrounding the two catalytic aspartic acid residues are absolutely conserved.

The $\mathrm{N}$-terminus of the mature enzyme starts at position 79 (Fig. 2), as determined by Edman sequencing of pure GcSAP. Most aspartic proteinases possess a pro-sequence of 50 residues (Davies, 1990) and a preprosequence of $70-80$ residues and the predicted preprosequence in GcSAP (78 residues) is typical. It contains a hydrophobic core signal sequence from position 3 to 12 
and there is a putative signal peptidase cleavage site between residues 16 and 17 (Fig. 2). Cleavage here would yield a protein with a pro-sequence of 62 amino acids. The pro-sequence contains multiple basic residues including three pairs of basic residues; basic residues are common in pro-sequences of aspartic proteinases (Davies, 1990). The last of the paired basic residues $\left(\mathrm{Lys}_{77}-\mathrm{Arg}_{78}\right)$ is adjacent to the mature $\mathrm{N}$-terminus and is probably the cleavage site of a KEX2-type processing enzyme (Bussey, 1988). The other basic amino acid residues in the pro-sequence may bind to the active site aspartic acid residues, as proposed for pepsinogen (James \& Sielecki, 1986), thus giving the pro-sequence a possible role in self-inhibition of pro-GcSAP. Based on comparisons with pepsinogen, probable candidates are $\operatorname{Arg}_{39}, \operatorname{Arg}_{53}$ and $\mathrm{Lys}_{54}$ as they are each adjacent to a tyrosine residue, which in pepsinogen stabilizes the interaction by hydrogen-bonding to the active site aspartic acids.

There are no Asn-Xxx- ${ }^{\mathrm{Ser}} / \mathrm{Thr}$ motifs in the sequence and hence no potential sites for $\mathrm{N}$-glycosylation. The SDS-PAGE-estimated $M_{\mathrm{r}}$ of 36000 is consistent with a deduced $M_{\mathrm{r}}$ of 34200 .

GcSAP contains only two Cys residues, at positions 332 and 365 (Fig. 2). These residues align with conserved Cys residues in other aspartic proteinases (Fig. 3) which are known to form a disulphide bond (Cutfield et al., 1995). Interestingly, GCSAP does not possess the first pair of conserved Cys residues (positions 133 and 145, Fig. 3) beyond the first active site aspartic residue. This disulphide bond loop is common in many aspartic proteinases, but it is clearly not essential for activity because it is not present in some other aspartic proteinases, for example endothiopepsin and penicillopepsin (Cutfield et al., 1995).

Many filamentous fungi and some yeasts secrete aspartic proteinases; for example, C. albicans, the common human fungal pathogen, possesses at least eight genes encoding enzymes of this type (Hube et al., 1994) and Rhizopus species such as $R$. niveus also have a similar family (Delaney et al., 1987). Other examples include Aspergillus awamori, Mucor miebei and Endothia parasitica (for a review see Ward \& Kodama, 1991). The properties of the GcSAP as determined in this study, for example $M_{r}$, conserved regions of amino acid sequence, inhibition by pepstatin and optimum activity at acidic $\mathrm{pH}$ values, are consistent with those for other fungal aspartic proteinases.

Although the sequence identity of aspartic proteinases from diverse sources is often no greater then $20-27 \%$, the crystal structures of numerous members of the family have revealed common features such as a predominance of $\beta$ structure and organization of the polypeptide into two domains with the two DTG motifs in the extended active site cleft (Cutfield et al., 1995). GcSAP will undoubtedly have these general features, together with unique detailed features. With the molecular cloning of the cDNA for GcSAP it will now be possible to assess the role of the enzyme in pathogenicity by a targeted gene disruption.

\section{ACKNOWLEDGEMENTS}

This research was supported by contract UOO 401 provided by the New Zealand Foundation for Research Science and Technology. We are grateful for the assistance of the Protein Micro-Chemistry Facility, Biochemistry Department, University of Otago, for the protein sequencing work. Nucleotide sequencing was performed by the Centre for Gene Research, Biochemistry Department, University of Otago. We thank Mrs Lana Ellis for technical assistance with the Northern analysis.

\section{REFERENCES}

Ausubel, F. M., Brent, R., Kingston, R. E., Moore, D. D., Seidman, J. G., Smith, J. A. \& Struhl, K. (1992). The polymerase chain reaction. In Short Protocols in Molecular Biology, 2nd edn. New York: Wiley.

Aviles, F. X. (1993). Innovations in Proteases and their Inhibitors. Berlin: Walter de Gruyter.

Bailey, J. A., O'Connell, R. J., Pring, R. J. \& Nash, C. (1993). Infection strategies of Colletotrichum species. In Colletotrichum: Biology, Pathology and Control, pp. 88-120. Edited by J. A. Bailey \& M. J. Jeger. Wallingford: CAB International.

Bowen, J. K., Templeton, M. D., Sharrock, K. R., Crowhurst, R. N. \& Rikkerink, E. H. A. (1995). Gene inactivation in the plant pathogen Glomerella cingulata: three strategies for the disruption of the pectin lyase gene pnlA. Mol Gen Genet 246, 196-205.

Bussey, H. (1988). Proteases and the processing of precursors to secreted proteins in yeast. Yeast 4, 17-26.

Carlson, M. \& Botstein, D. (1982). Two differentially regulated mRNAs with different $5^{\prime}$ ends encode secreted and intracellular forms of yeast invertase. Cell 28, 145-154.

Collmer, A. \& Keen, N. T. (1986). The role of pectic enzymes in plant pathogenesis. Annu Rev Phytopathol 24, 383-409.

Cooper, R. M. (1977). Regulation and synthesis of cell-walldegrading enzymes of plant pathogens. In Cell Wall Biochemistry, pp. 163-206. Edited by B. Solheim \& J. Raa. Oslo: Universitetsforlaget.

Cutfield, S. M., Dodson, E. J., Anderson, B. F., Moody, P. C. E., Marshall, C. J., Sullivan, P. A. \& Cutfield, J. F. (1995). The crystal structure of a major secreted aspartic proteinase from Candida albicans in complexes with two inhibitors. Structure 3, 1261-1271.

Davies, D. R. (1990). The structure and function of the aspartic proteinases. Annu Rev Biophys Biophys Chem 19, 189-215.

Delaney, R., Wong, R. N. S., Meng, G., Wu, N. \& Tang, J. (1987). Amino acid sequence of rhizopuspepsin isozyme p15. J Biol Chem 262, 1461-1467.

Gray, G. L., Hayenga, K., Cullen, D., Wilson, L. J. \& Norton, S. (1986). Primary structure of Mucor miehei aspartyl protease: evidence for a zymogen intermediate. Gene 48, 41-53.

Gurr, S. J., Unkles, S. E. \& Kinghorn, J. R. (1987). The structure and organization of nuclear genes of filamentous fungi. In Gene Structure in Eukaryotic Microbes, pp. 93-139. Edited by J. R. Kinghorn. Oxford: IRL Press.

Horiuchi, H., Yanai, K., Okazaki, T., Takagi, M. \& Yano, K. (1988). Isolation and sequencing of a genomic clone encoding aspartic proteinase of Rhizopus niveus. J Bacteriol 170, 272-278. 
Hube, B., Monod, M., Schofield, D. A., Brown, A. J. P \& Gow, N. A. R. (1994). Expression of seven members of the gene family encoding secretory aspartyl proteinases in Candida albicans. Mol Microbiol 14, 87-99.

Hwang, C.-S. \& Kollatukudy, P. E. (1995). Isolation and characterisation of genes expressed uniquely during appressorium formation by Colletotrichum gloeosporioides conidia induced by the host surface wax. Mol Gen Genet 247, 282-294.

Irwin, J. A. H. \& Cameron, D. F. (1978). Two diseases of Stylosanthes spp. caused by Colletotrichum gloeosporioides in Australia and pathogen specialisation within one of the causal organisms. Aust J Agric Res 29, 305-317.

James, M. N. G. \& Sielecki, A. R. (1983). Structure and refinement of penicillo-pepsin at $1 \cdot 8 \AA$ resolution. J Mol Biol 163, 299-361.

James, M. N. G. \& Sielecki, A. R. (1986). Molecular structure of an aspartic proteinase zymogen, porcine pepsinogen, at $1.8 \AA$ resolution. Nature 319, 33-38.

Kuc, J. \& Williams, E. B. (1962). Production of proteolytic enzymes by four pathogens of apple fruit. Phytopathology 52, 739.

Laemmli, U. K. \& Favre, M. (1973). Phage T4 head assembly. $J$ Mol Biol 80, 575-599.

MacDonald, F. \& Odds, F. C. (1980). Inducible proteinase of Candida albicans in diagnostic serology and the pathogenesis of systemic candidosis. J Med Microbiol 13, 423-435.

Mordue, J. E. M. (1971). Glomerella cingulata. CMI/AAB Descriptions of Pathogenic Fungi and Bacteria, No. 315.

Movahedi, S. \& Heale, J. B. (1990). Purification and characterisation of an aspartic proteinase secreted by Botrytis cinerea per. ex. pers. in culture and in infected carrots. Physiol Mol Plant Pathol 36, 289-302.

Ogrydziak, D. M. (1993). Yeast extracellular proteases. Crit Rev Biotechnol 13, 1-55.

Peng, J. H. \& Black, L. L. (1976). Increased proteinase inhibitor activity in response to infection of resistant tomato plants by Phytophthora infestans. Phytopathology 73, 664-670.

Raeder, U. \& Broda, P. (1985). A rapid method for the purification of fungal DNA. Lett Appl Microbiol 1, 17-20.

Rikkerink, E. H. A., Solon, S. L., Crowhurst, R. N. \& Templeton, M. D. (1994). Integration of vectors by homologous recombination in the plant pathogen Glomerella cingulata. Curr Genet 25, 202-208.

Roby, D., Toppan, A. \& Esquerre-Tugaye, M. T. (1987). Cell surfaces in plant micro-organism interactions. VIII. Increased proteinase inhibitor activity in melon plants in response to infection by Colletotrichum lagenarium or to treatment with an elicitor fraction from this fungus. Physiol Mol Plant Pathol 30, 453-460.

Ross, I. K., De Bernardis, F., Emerson, G. W., Cassone, A. \& Sullivan, P. A. (1990). The secreted aspartate proteinase of Candida albicans: physiology of secretion and virulence of a proteinase-deficient mutant. J Gen Microbiol 136, 687-694.

Ryan, C. A. (1973). Proteolytic enzymes and their inhibitors in plants. Annu Rev Plant Physiol 24, 173-196.

Sambrook, J., Fritsch, E. F. \& Maniatis, T. (1989). Molecular Cloning: a Laboratory Manual, 2nd edn. Cold Spring Harbor, NY: Cold Spring Harbor Laboratory.

Smith, P. K., Krohn, R. I., Hermanson, G. T., Mallia, A. K., Gartner, F. H., Provenzano, M. D., Fujimoto, E. K., Goeke, N. M., Olson, B. J. \& Klenk, D. C. (1985). Measurement of protein using bicinchoninic acid. Anal Biochem 150, 76-85.

Teeri, T. T., Kumar, V., Lehtovaara, P. \& Knowles, J. (1987). Construction of cDNA libraries by blunt-end ligation: high frequency cloning of long cDNAs from filamentous fungi. Anal Biochem 164, 60-67.

Templeton, M. D., Rikkerink, E. H. A., Solon, S. L. \& Crowhurst, R. N. (1992). Cloning and molecular characterization of the glyceraldehyde-3-phosphate dehydrogenase-encoding gene and cDNA from the plant pathogenic fungus Glomerella cingulata. Gene 122, 225-230.

Vogelstein, B. \& Gillespie, D. (1979). Preparative and analytical purification of DNA from agarose. Proc Natl Acad Sci USA 76, 615-619.

Ward, M. \& Kodama, K. H. (1991). Introduction to fungal proteinases and expression in fungal systems. Adv Exp Med Biol 306, 149-160.

Ward, M. \& Turner, G. (1986). The ATP synthase subunit 9 gene of Aspergillus nidulans: sequence and transcription. Mol Gen Genet 205, 331-338.

Wickerham, L. J. (1946). A critical review of the nitrogen assimilation tests commonly used in the classification of yeasts. $J$ Bacteriol 52, 293-301.

Wright, R. J., Carne, A., Hieber, A. D., Lamont, I. L., Emerson, G. E. \& Sullivan, P. A. (1992). A second gene for a secreted aspartate proteinase in Candida albicans. J Bacteriol 174, 7848-7853.

Received 22 October 1996; accepted 4 December 1996. 